\title{
Temporary emersion enhances amphibious Isoetes production
}

\author{
Eglantine Chappuis, Enric Ballesteros and Esperança Gacia*
}

Biogeodynamics and Biodiversity Group, Centre d'Estudis Avançats de Blanes, CEAB-CSIC, Ctra. Accés Cala St. Francesc 14, 17300 Blanes, Spain.

* Corresponding author: gacia@ceab.csic.es

Received: 05/05/2016 Accepted: 31/08/2016

\begin{abstract}
Temporary emersion enhances amphibious Isoetes production

Annual primary production of two amphibious quillworts was measured in two contrasting temporary environments in NE Spain: Isoetes echinospora growing in a high mountain semipermanent pool and Isoetes delilei growing in a Mediterranean pool. Leaf primary production showed a unimodal distribution with a peak in July for I. echinospora and in April for I. delilei. The population of I. echinospora produced $38.7 \mathrm{~g} \mathrm{DW} \mathrm{m}^{-2} \mathrm{y}^{-1}\left(15.5 \mathrm{~g} \mathrm{C} \mathrm{m}^{-2} \mathrm{y}^{-1}\right)$ of leaves the year of complete submersion, but leaf production increased to $49.3 \mathrm{~g} \mathrm{DW} \mathrm{m}^{-2} \mathrm{y}^{-1}\left(19.7 \mathrm{~g} \mathrm{C} \mathrm{m}^{-2} \mathrm{y}^{-1}\right)$ the year with two months of emersion (27.4\% increase). Leaf production of $I$. delilei also increased significantly after emersion (the pool dries out annually) and reached an annual leaf production of $676.7 \mathrm{~g} \mathrm{DW} \mathrm{m}^{-2} \mathrm{y}^{-1}\left(265.3 \mathrm{~g} \mathrm{C} \mathrm{m}^{-2} \mathrm{y}^{-1}\right)$. I. delilei leaf production was 15 times higher than I. echinospora and much higher than the described range for submerged isoetids. The production increase of I. echinospora under temporal emersion together with the unusual high production of I. delilei thriving in temporary pools suggests that temporal emersion enhance amphibious isoetid production.
\end{abstract}

Key words: Leaf marking technique, NPP, Pyrenees, Albera Massif, soft-water lake, vernal pool, temporary pond, Isoetes setacea.

\section{RESUMEN}

La emersión temporal aumenta la producción de los Isoetes anfibios

En este trabajo se ha medido la producción primaria anual de dos isoetes anfibios en dos sistemas temporales diferentes en el NE de España: Isoetes echinospora, en una charca semipermanente de alta montaña y Isoetes delilei, en una charca temporal mediterránea. La producción primaria de las hojas mostró una distribución unimodal con un máximo en julio para I. echinospora y en abril para I. delilei. La población de I. echinospora produjo $38.7 \mathrm{~g} \mathrm{PS} \mathrm{m}^{-2} \mathrm{y}^{-1}\left(15.5 \mathrm{~g} \mathrm{C} \mathrm{m}^{-2} \mathrm{y}^{-1}\right)$

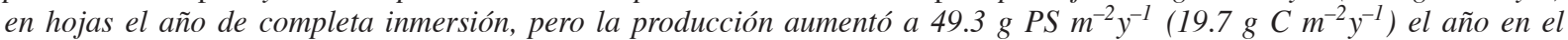
que las plantas estuvieron emergidas durante dos meses (incremento del 27.4\%). La producción de hojas de I. delilei también aumentó significativamente después de la emersión (la charca se seca anualmente) y alcanzó una producción anual de $676.7 \mathrm{~g}$ $P S m^{-2} y^{-1}\left(265.3 \mathrm{~g} \mathrm{C} \mathrm{m}^{-2} y^{-1}\right)$. La producción primaria de hojas de I. delilei fue 15 veces mayor que la de I. echinospora y muy superior a los rangos descritos para los isoétidos submergidos. El incremento de producción de I. echinospora en condiciones de emersión temporal junto con la inusual y elevada producción de I. delilei en una charca temporal, sugieren que la emersión temporal aumenta la producción primaria en los isoetes anfibios.

Palabras clave: Técnica de marcado de hojas, NPP, Pirineos, Macizo de la Albera, lago de aguas blandas, laguna temporal, Isoetes setacea.

\section{INTRODUCTION}

The quantification of primary production in aquatic macrophytes is important for evaluating ecological functions and has been used as an indicator of trophic status of aquatic systems (e.g. Krause \& King, 1994; Penning et al., 2008; FlorArnau et al., 2015). Furthermore, the knowledge 
on macrophyte primary production is essential to understand nutrient cycles and the role of macrophytes in global climate change and $\mathrm{CO}_{2}$ fertilization (e.g. Ding et al., 2003; Saunders et al., 2014; Verspagen et al., 2014). In shallow environments, aquatic macrophyte production is often more important than other primary producers such as phytoplankton and epiphytes (Nõges et al., 2010). However, primary productivity differs significantly among continental aquatic systems (i.e. wetlands exhibit greater primary productivity than lakes and streams; Whittaker \& Likens, 1973) and aquatic macrophytes (Madsen et al., 2002; Tamire \& Mengistou, 2014). Helophytes generally produce more than hydrophytes (Tamire \& Mengistou, 2014) and elodeids are more productive than isoetids (Madsen et al., 2002).

Despite a low primary production, isoetid populations are important worldwide in terms of abundance and functioning, especially in softwater lakes and also in temporary pools (Smolders et al., 2002; Bagella \& Caria, 2012; Vila-Costa et $a l ., 2016)$. The genus Isoetes or quillworts include about 100 species with $60 \%$ being aquatic. Quillworts are slow growing plants with leaves displayed in a helicoidal rosette over a bi- or trilobulate corm. Both Isoetes echinospora Durieu and Isoetes delilei Rothm. lose all their leaves during the disfavourable season, but the corm persists for several years, and both are amphibious plants. I. echinospora usually thrives submerged in shallow soft-waters from oligotrophic lakes in N-America and Europe (Boivin, 1961; Seddon, 1965). Spain is the southernmost distribution limit in Europe, where it is relatively abundant in oligotrophic high mountain lakes of the Pyrenees and is also found in semipermanent pools that may eventually dry out in summer (Gacia et al., 1994). I. delilei is a rare western Mediterranean quillwort that thrives in temporary pools with a relatively long inundation period (Molina, 2005). Mediterranean temporary pools represent unique species-rich habitats with many rare and endangered species (Deil, 2005; Bagella \& Caria, 2012). Specifically, Isoetes delilei is a key species determining a priority habitat for the European Union (Habitats Directive 92/43/EEC) with declining populations, which qualifies for a Nearly Threatened species in Europe (Rhazi, 2010). The decline is due to agricultural and development pressures as well as land abandonment (Rhazi, 2010) that favors the invasion of competing shrubs and trees (Rhazi et al., 2004).

Amphibious plants grow both in terrestrial as well as aquatic environments and, consequently, are well adapted to seasonal or fluctuating aquatic ecosystems. Water has been considered as a less suitable habitat for plant growth than the terrestrial environment (Maberly \& Spence, 1989) because of reduced light and $\mathrm{CO}_{2}$ availability. However, to our knowledge, the primary production of seasonal habitats and amphibious macrophyte species has not been studied. Nielsen \& Sand-Jensen (1997) and Robe \& Griffiths (1998) study the growth rate and other adaptations of Littorella uniflora to an amphibious life, but primary production is not calculated.

The aim of this work is to calculate the primary production of I. echinospora growing in a semipermanent pool (occasionally dries in summer) and I. delilei in a temporary pool (dries every summer). We used a leaf marking technique for in situ measurements of primary production (Gacia \& Ballesteros, 1991) supplemented by a description of the leaf growing pattern (Gacia \& Ballesteros, 1994).

\section{MATERIALS AND METHODS}

\section{Study sites and species}

The studied I. echinospora population thrived in Baciver pool, a small (ca. $20 \mathrm{~m}^{2}$ ) semipermanent pond adjacent to Lake Baciver (Spanish Pyrenees, $42^{\circ} 41^{\prime} 46^{\prime \prime} \mathrm{N}, 0^{\circ} 59^{\prime} 1^{\prime \prime} \mathrm{E}$ ) situated at $2120 \mathrm{~m}$ a.s.l. under a subalpine climate with high precipitation $(>1100 \mathrm{~mm} / \mathrm{y})$. The surface of the pool remains frozen half of the year and a large amount of snow accumulates during winter and early spring, similarly to the adjacent lake (Catalan et al., 1990; Gacia \& Ballesteros, 1994). Some years the shallow pool stayed flooded over the summer, while it dried during summer on other years. Lake Baciver was dammed after the fieldwork finished and the semipermanent pool 
no longer exists but populations of the same species exist in nearby pools.

The studied $I$. delilei population thrived in Sendu pool (Northeastern Spain, 42 $22^{\prime} 50^{\prime \prime} \mathrm{N}$, $\left.2^{\circ} 56^{\prime} 30^{\prime \prime} \mathrm{E}\right)$, a relatively small $\left(5000 \mathrm{~m}^{2}\right)$ temporary pond situated at $113 \mathrm{~m}$ a.s.l. under a Mediterranean temperate climate with relatively low precipitation (ca. $600 \mathrm{~mm} / \mathrm{y}$ ). The pool generally floods in autumn or winter and dries out in spring. This species was previously identified as Isoetes setacea Bosc ex Delile (non Lamarck), a name that is not valid, as Lamarck previously described Isoetes setacea Lam., a completely different species that now is under synonymy with Isoetes lacustris (Greuter \& Troia, 2015). In the same study, Greuter \& Troia (2015) concluded that the correct name of the Mediterranean species generally misnamed $I$. setacea is I. delilei.

\section{Environmental factors}

Water samples were collected at the central part of each pool and kept frozen until analysis. A total of 6 abiotic variables were considered: $\mathrm{pH}$, alkalinity, nitrate, nitrite, ammonia and phosphate (Table 1). Water chemistry variables were analyzed according to the standard methods described in Chappuis et al. (2014) for Sendu pool and as described in Gacia \& Ballesteros (1993) and Gacia et al. (1994) for Baciver pool. pH was measured in situ with an electrode, alkalinity was determined by titration and nutrients were mainly measured by colorimetric analysis.

\section{Production}

Leaf production and loss (number of leaves) were determined using a leaf marking technique (Gacia \& Ballesteros, 1991) during the full growing season of the species. I. echinospora was marked from June 1988 to October 1989 (two growing seasons) and I. delilei was followed from January 2009 to June 2009 (one growing season). Even though the production of both species was measured in different years, the data is still comparable as the differences between climate types (subalpine vs. Mediterranean temperate climate) is much greater than the annual fluctuations. The linear leaves of the Isoetes species are easy to mark with small metallic rings and, as new leaves are produced at the center of the rosette, leaf production and loss over time is easy to track (Gacia \& Ballesteros, 1991). Thirty-two individuals of each species were identified by a knot code in a short nylon thread, firmly attached to the sediment by a small nail. All leaves of each individual were marked with $4 \mathrm{~mm}$ diameter copper wire rings. About one month later, the remaining marked leaves (old) and unmarked leaves (new) were counted for each individual. The number of lost leaves was estimated from the difference between initial and remaining marked leaves. The process was repeated 6 times per growing season and species (12 measures for I. echinospora and 6 for I. delilei).

Leaf biomass production was estimated based on leaf production and loss following Gacia \& Ballesteros (1994). The biomass of the new leaves

Table 1. Water chemistry variables at the two studied sites. Variables químicas del agua en los dos sitios de estudio.

\begin{tabular}{|c|c|c|c|c|}
\hline \multirow[b]{2}{*}{ Variable } & \multirow[b]{2}{*}{ Units } & \multicolumn{2}{|c|}{$\begin{array}{c}\text { Baciver pool } \\
\text { Isoetes echinospora }\end{array}$} & \multirow{2}{*}{$\begin{array}{c}\text { Sendu pool } \\
\text { Isoetes delilei } \\
\text { Mean }\end{array}$} \\
\hline & & Min & Max & \\
\hline $\mathrm{pH}$ & & 5.56 & 8.51 & 7.28 \\
\hline Alkalinity & $\mu e q / 1$ & 17 & 150 & 693 \\
\hline $\mathrm{NO}_{3}^{-}$ & $\mu \mathrm{M}$ & 0 & 3.92 & 2.46 \\
\hline $\mathrm{NO}_{2}^{-}$ & $\mu \mathrm{M}$ & 0.016 & 0.09 & 0.30 \\
\hline $\mathrm{NH}_{4}^{+}$ & $\mu \mathrm{M}$ & 0.64 & 14.06 & 0.96 \\
\hline $\mathrm{PO}_{4}^{3-}$ & $\mu \mathrm{M}$ & 0.02 & 0.24 & 1.01 \\
\hline
\end{tabular}


produced and the elongation of the remaining old ones in a certain time interval allow us to estimate the production of leaf biomass ( $\mathrm{g}$ DW). The population density of individuals was determined in situ with three replicates of $20 \times 20 \mathrm{~cm}$. Tissue carbon content was analyzed for both species in order to also express production in terms of $g$
C. Clean leaf tissue of several individuals were dried and homogenized prior to analysis. I. echinospora carbon content was determined with a Carlo-Erba 1500 Analyser and I. delilei carbon content was determined by EA-IRMS (Elemental Analyzer -Isotope Ratio Mass Spectrometer) using a PDZ Europa ANCA-GSL elemental an-

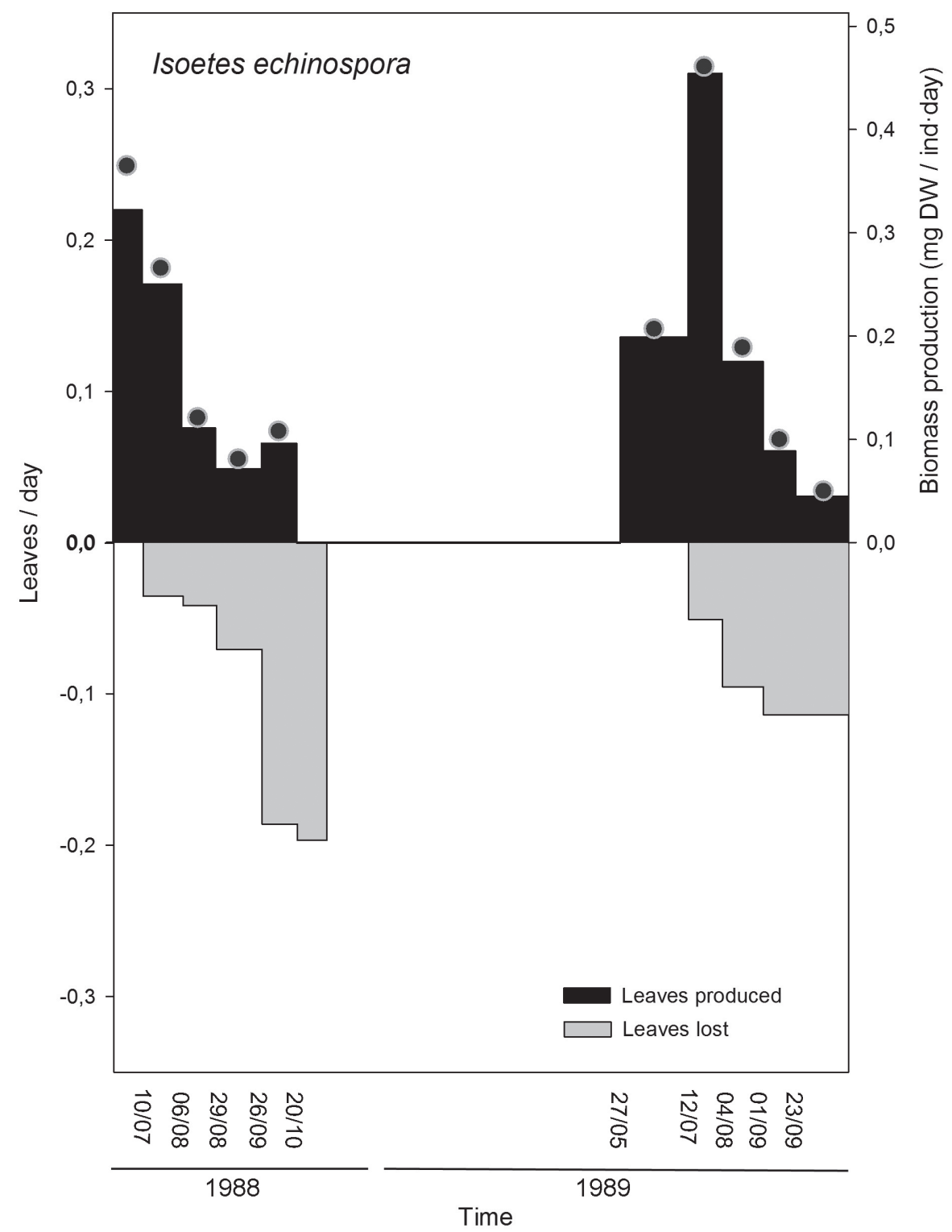

Figure 1. Leaf production and loss rates for Isoetes echinospora individuals during the growing seasons of 1988 and 1989 . The average biomass production rate per individual is also shown as dark grey dots. Tasas de producción y pérdida de hojas para individuos de Isoetes echinospora en los períodos de crecimiento de 1988 y 1989. La tasa promedio de producción de biomasa por individuo se muestra con puntos de color gris oscuro. 
alyzer interfaced to PDZ Europa 20-20 isotope ratio mass spectrometer (Sercon Ltd, Cheshire, UK). All plots and regressions were performed with SigmaPlot 12.0.

\section{RESULTS}

Baciver pool is a soft-water pond with $\mathrm{pH}$ concentrations that varied greatly (see detailed daily profiles in Gacia \& Ballesteros, 1993) as shown in Table 1. Dissolved inorganic nitrogen also varied greatly but always within the oligotrophic state. Ammonia showed the highest concentration among DIN forms (Table 1), probably due to sporadic cattle presence. Dissolved phosphorus fluctuated but within the low range that corresponds to oligotrophic waters (Wetzel, 1981; Catalan et al., 2006). After ice melting, water level was rather constant at $50 \mathrm{~cm}$ over the summer and autumn of 1988. In contrast, water level gradually decreased and the pool dried out at the end of July 1989, but soil and plants were always moist until the pool flooded again in early October. Water transparency was high and light always reached the bottom of the pool.

Sendu pool shows harder waters than Baciver pool and a rather neutral pH (Table 1). Dissolved inorganic nitrogen values were within oligotrophic ranges but dissolved phosphorus was slightly within the eutrophic range (Wetzel, 1981) as shown in Table 1. The pool flooded around New Year and the highest water level was measured in February with a maximum depth of $55 \mathrm{~cm}$. Plots with marked plants were situated at intermediate depths $(33 \mathrm{~cm}$ of water depth in February). Water level gradually decreased and plots were dry by the end of April but still moist. Soil and plants were dry in May and June except for occasional rain. Water transparency was high and light always reached the bottom of the pool even if some filamentous algae appeared in March and April.

Both species completely changed the leaves every year and showed a highly seasonal leaf production. I. echinospora started producing leaves around June (Fig. 1), depending on the ice cover thawing. Maximum leaf production (both in terms of number and biomass) was reached in July, but the peak was higher in 1989, when the plants were emerged, than in 1988 , when the plants were submerged (Fig. 1). Leaf production was low in autumn and all leaves were dead by November (Fig. 1). I. delilei started producing leaves in January, shortly after pool inundation (Fig. 2). Even if the production rate of new leaves was rather constant, the biomass production peaked in April due to an important leaf elongation that occurred right when the plots dried out. Leaf loss peaked at the end of the growing season (May and June) when the pool and soil were completely dry and all leaves were dead by mid June (Fig. 2).

I. echinospora showed the same biomass per leaf distribution within the rosette along both growing seasons and both years. Consequently, one general hyperbolic regression was calculated for this species (Fig. 3). In contrast, we found two distributions of biomass per leaf within the rosette along the growing season for I. delilei. From January to March, coinciding with the submerged period, I. delilei plants were small and had leaves with low biomass (Fig. 3). In April, the plots dried out and all leaves elongated with a consequent important biomass increase (Fig. 2 and 3). Therefore, two hyperbolic regressions were fitted for I. delilei corresponding to these two differentiated periods (Fig. 3). I. echinospora showed much lower maximum biomass per leaf (0.002 g DW, Fig. 3) than I. delilei (0.009 g DW for early season plants and $0.03 \mathrm{~g}$ DW for late season plants, Fig. 3).

Leaf turnover rates were slightly higher for I. echinospora (Table 2) but leaf production was slightly faster in I. delilei (leaf plastochrone interval of 9.2 days compared to 12.6 days, Table 2). Hence, I. delilei produced a total of 18.2 leaves per plant on average and 16.6 leaves for I. echinospora plants during their annual growing period of about 5 months. A slightly higher leaf production combined with higher leaf biomass resulted in higher annual biomass production for I. delilei (0.29 g DW per plant) than for I. echinospora (0.03 g DW per plant).

Plant density varied greatly for I. echinospora and increased through the growing season for 
both years. Plant density started as low as 1242 plants $/ \mathrm{m}^{2}$, ended up with 2663 plants $/ \mathrm{m}^{2}$ and had an average of $1948.9 \mathrm{plants} / \mathrm{m}^{2}$. Considering plant density, I. echinospora population had an average annual leaf production of $44.0 \mathrm{~g} \mathrm{DW} / \mathrm{m}^{2}$ (Table 2). Leaf production was a $27.4 \%$ higher the year of emersion (1989) than the year without emersion (1988). Plant density was stable for $I$. delilei with an average value of 2307.5 plants $/ \mathrm{m}^{2}$, which yields to an annual leaf production of $676.7 \mathrm{~g} \mathrm{DW} / \mathrm{m}^{2}$ (Table 2). Carbon content is similar for both species: $40.0 \%$ for I. echinospora and $39.2 \%$ for I. delilei. Hence, the annual leaf production of I. echinospora was $17.6 \mathrm{~g} \mathrm{C} / \mathrm{m}^{2}$

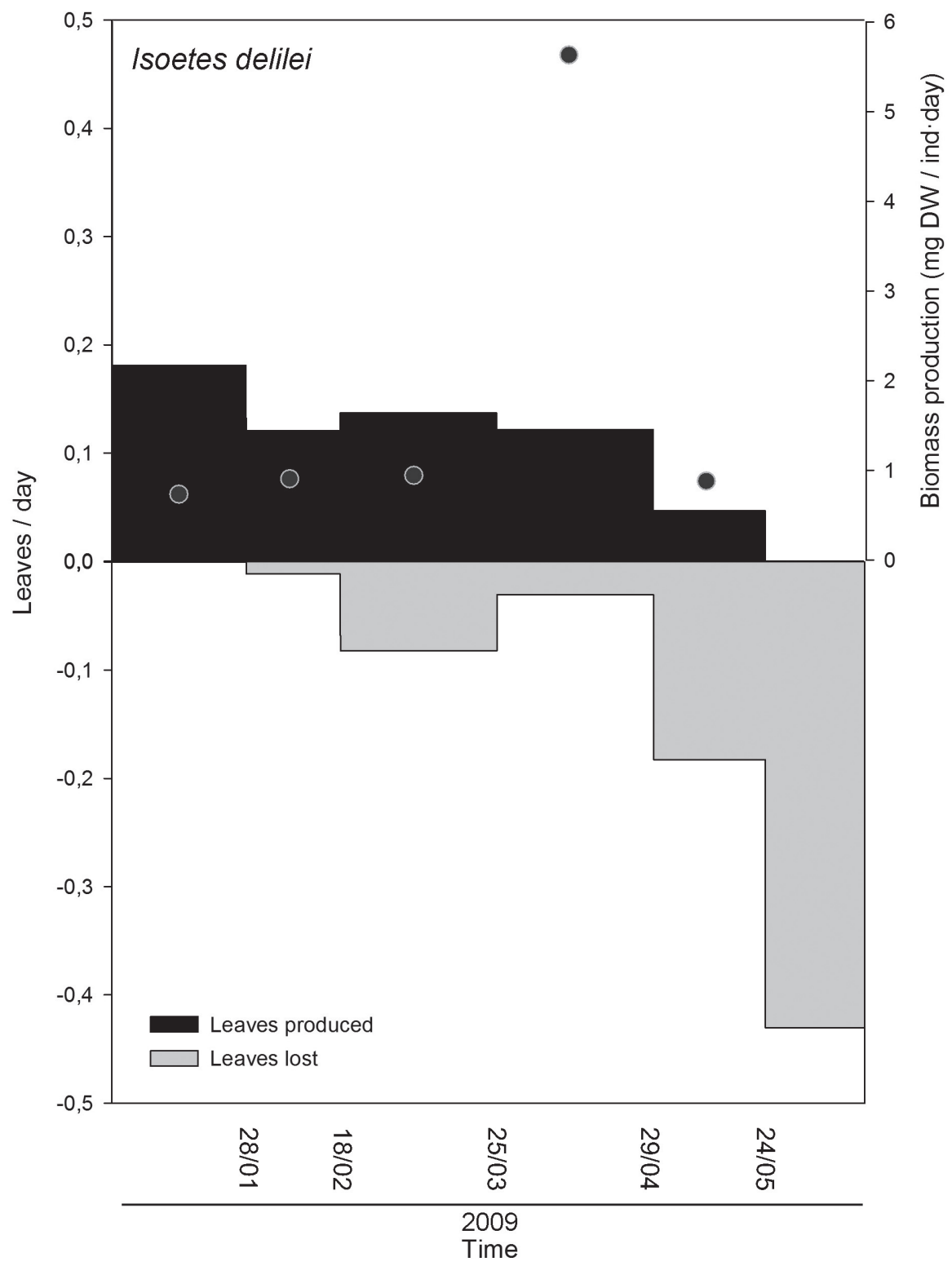

Figure 2. Leaf production and loss rates for Isoetes delilei individuals during the growing season of 2009. The average biomass production rate per individual is also shown as dark grey dots. Note the different scales of y-axes used in comparison to figure 1. Tasas de producción y pérdida de hojas para individuos de Isoetes delilei en el período de crecimiento de 2009. La tasa promedio de producción de biomasa por individuo se muestra con puntos de color gris oscuro. La escala del eje y es distinta a la de la figura 1. 

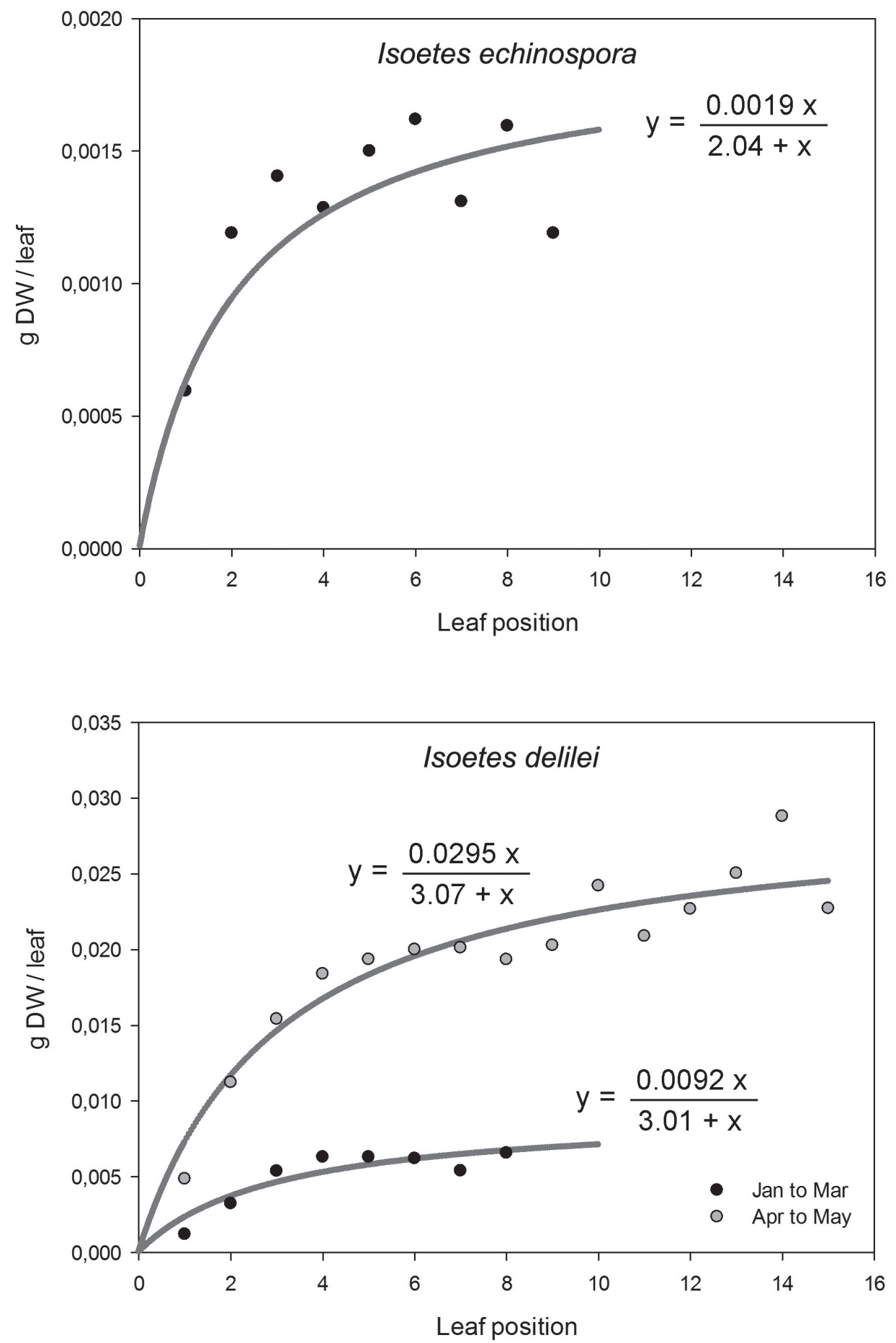

Figure 3. Leaf biomass (in dry weight $[D W], y)$ versus its position in the shoot $(x)$. Significant hyperbolic regressions and the fitted formula are shown. Note the different scale of $y$-axis used for each species. Biomasa de las hojas (en peso seco [PS], y) versus su posición en la roseta (x). Se muestran las regresiones hiperbólicas significativas y sus fórmulas. La escala del eje y es distinta para cada especie. 
Table 2. Leaf turnover rates (annual), leaf plastochrone interval (growing season) and leaf production (annual) for Isoetes echinospora and Isoetes delilei populations. Tasa de renovación de hojas (anual), intervalo plastocrónico de las hojas (periodo de crecimiento) y producción de hojas (anual) para poblaciones de Isoetes echinospora $e$ Isoetes delilei.

\begin{tabular}{cccccc}
\hline Species & Year & $\begin{array}{c}\text { Leaf turnover rate } \\
\left(y^{-1}\right)\end{array}$ & $\begin{array}{c}\text { Leaf plastochrone } \\
\text { interval }(d)\end{array}$ & $\begin{array}{c}\text { Leaf production } \\
\left(\mathrm{g} \mathrm{DW} \mathrm{m}^{-2} \mathrm{y}^{-1}\right)\end{array}$ & $\begin{array}{c}\text { Leaf production } \\
\left(\mathrm{g} \mathrm{C} \mathrm{m}^{-2} \mathrm{y}^{-1}\right)\end{array}$ \\
\hline \multirow{2}{*}{ Isoetes echinospora } & 1988 & 1.62 & 14.0 & 38.7 & $\mathbf{1 5 . 5}$ \\
\cline { 2 - 6 } & 1989 & 1.52 & 11.6 & 49.3 & $\mathbf{1 9 . 7}$ \\
\hline Isoetes delilei & 2009 & 1.41 & 9.2 & 676.7 & $\mathbf{2 6 5 . 3}$ \\
\hline
\end{tabular}

and of I. delilei was $265.3 \mathrm{~g} \mathrm{C} / \mathrm{m}^{2}$ (Table 2). Thus, I. delile $i$ leaf production per square meter was $15-$ fold higher than in I. echinospora.

\section{DISCUSSION}

Growth of both species showed a unimodal pattern that followed water availability but also irradiance and temperature (Gacia \& Ballesteros, 1994). The I. echinospora population thrives in a high altitude pool under a cold high mountain climate and, consequently, the highest leaf and biomass production concentrates in summer as observed for other aquatic isoetids (Madsen et al., 2002). The annual production of I. echinospora was significantly lower than the shallow I. lacustris population occurring in the neighbouring Baciver lake $\left(75 \mathrm{~g} \mathrm{DW} / \mathrm{m}^{2}\right.$.y at $-0.8 \mathrm{~m}$, Gacia \& Ballesteros, 1994). Annual production was higher the year of emersion, which confirms that this species is well adapted to the amphibious life and suggests that emersion enhances productivity and growth rates in amphibious isoetids (Robe \& Griffiths, 1998).

In contrast, I. delilei thrives in Mediterranean temporary pools that generally dry out in summer. Consequently, the highest leaf biomass production was observed in early spring after emersion at the same time that temperature and irradiance increased. However, the same population of I. delile $i$ was visited several times the previous year (winter and early spring of 2007-08) when the pool almost did not flood and we observed an extremely reduced plant production and growth period length. Hence, the presence of an initial relatively long flooding period seems to be a key factor for I. delilei production, as observed for other amphibious species (Casanova \& Brock, 2000).

The increased leaf production with emersion observed for both species could have several possible causes. First, an increased $\mathrm{CO}_{2}$ supply could enhance photosynthesis. Submerged Isoetes obtain a considerable amount of $\mathrm{CO}_{2}$ from the sediment pool through root absorption, which allow them to ameliorate the low $\mathrm{CO}_{2}$ bulk water concentration (Madsen et al., 2002). However, Isoetes delilei leaves have stomata (Pfeiffer, 1922), which allow the use of $\mathrm{CO}_{2}$ from the air when emerged. Analyzed European I. echinospora had no stomata (Pfeiffer, 1922), in contrast with some of the American plants. However, I. echinospora is usually found submerged in Europe and leaves of emerged individuals should be analyzed. Actually, Gacia \& Ballesteros (1993) found lower titrable acidity (i.e. loss of CAM metabolism) in emerged compared to submerged I. echinospora leaves that could indicate the presence of stomata and the use of aerial $\mathrm{CO}_{2}$. Second, mineral nutrient supply may have increased under higher aerobic conditions of the sediment. Actually, the population of Isoetes lacustris thriving in the adjacent Baciver Lake was nutrient limited, especially by phosphorus, and showed an increased growth after nutrient addition (Gacia \& Ballesteros, 1994). Baciver pool had similar nutrient levels to the lake, I. echinospora and I. lacustris thrive in the same or similar lakes (Gacia et al., 1994) and, consequently, I. echinospora could also be nutrient limited. Sendu pool exhibited eutrophic levels of phosphorus but nitrogen was relatively low and the N:P ratio was of about 4:1. Therefore, I. delilei might be nitrogen limited and might respond positively to a nutrient increase. Third, higher irradiance could contribute 
to higher photosynthetic rates. However, submersed plants of I. lacustris do not seem to be limited by light (Chappuis et al., 2015) and that could also be the case for the species studied here. And last, higher maximum temperatures reached in the air also could enhance photosynthesis rates (Pokorný \& Květ, 2003). Probably more than one factor helped to increase the photosynthetic rate that resulted in higher leaf production associated with emersion but we believe that the increased $\mathrm{CO}_{2}$ supply plays a major role since $\mathrm{CO}_{2}$ is a largely reported limiting factor for productivity in extremely soft-water lakes (Murphy, 2002; Madsen et al., 2002) and emergent leaves have a much larger availability of $\mathrm{CO}_{2}$ than submerged ones (Sand-Jensen \& Frost-Christensen, 1999).

Isoetids have low productivity as a result of a relatively low biomass and low leaf turnover rates. Their annual productivity has been described to range from 5 to $425 \mathrm{~g} \mathrm{DW} / \mathrm{m}^{2}$ in the review of Madsen et al. (2002). The annual pro-

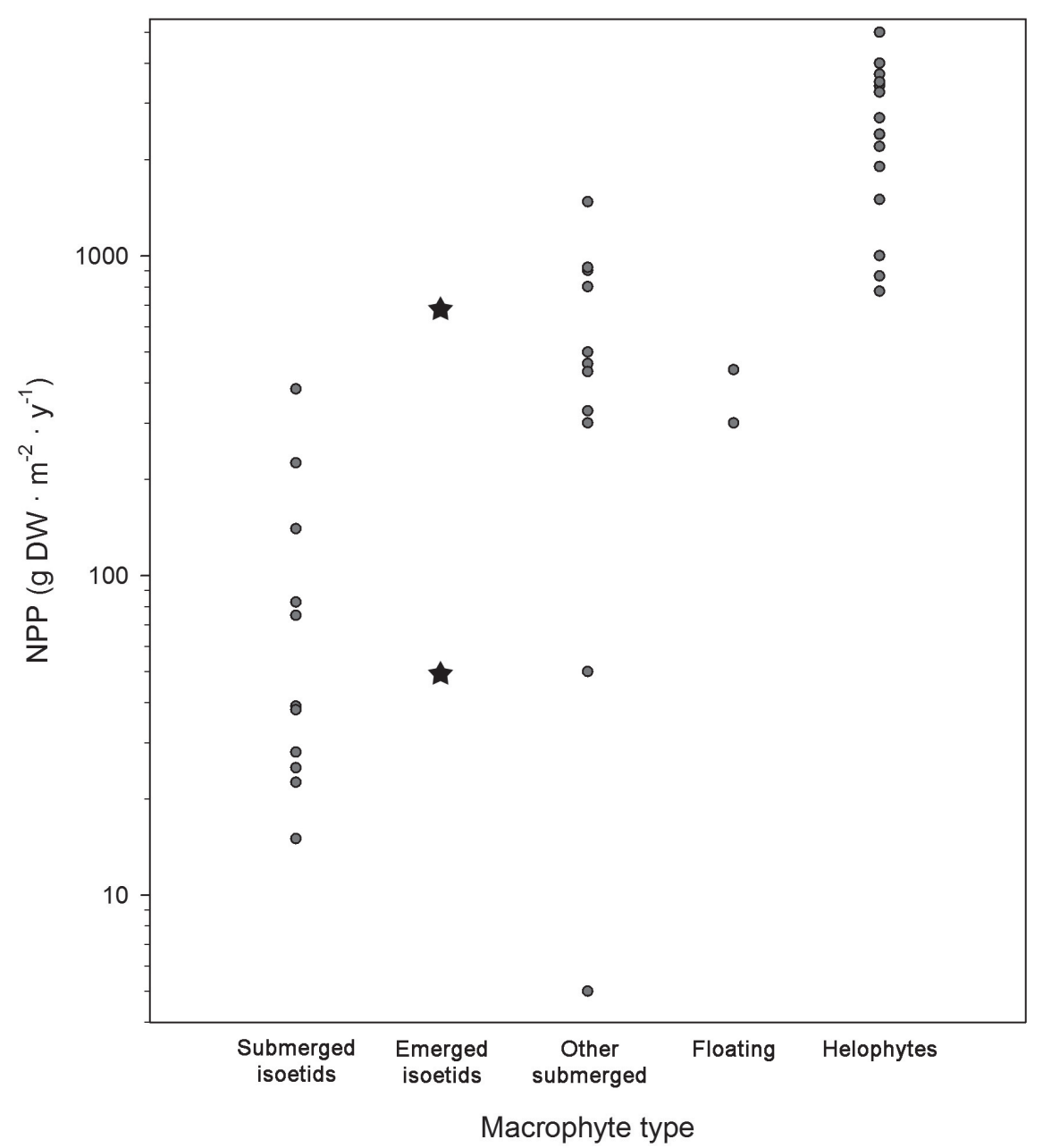

Figure 4. Annual net primary production (NPP) of different groups of macrophytes. Note that y-axis is in log scale. Different sources were used: Boston \& Adams (1987), Boston et al. (1989), Gacia \& Ballesteros (1994), Silva et al. (2009), Yu et al. (2010), Obrador \& Pretus (2010), Miller \& Fujii (2010), Tamire \& Mengistou (2014). Black stars: data provided by this study. Producción primaria neta anual (NPP) de distintos grupos de macrófitos. La escala del eje y es logarítmica. Distintas fuentes fueron usadas: Boston \& Adams (1987), Boston et al. (1989), Gacia \& Ballesteros (1994), Silva et al. (2009), Yu et al. (2010), Obrador \& Pretus (2010), Miller \& Fujii (2010), Tamire \& Mengistou (2014). Estrellas negras: datos obtenidos en el presente estudio. 
duction of I. echinospora (44 $\left.\mathrm{g} \mathrm{DW} \mathrm{m}^{-2} \mathrm{y}^{-1}\right)$ falls in the lower end of the range (Fig. 4). Actually, we did not estimate the underground production and the actual NPP would be higher (Gacia \& Ballesteros, 1994 estimated the underground production as acounting for 30-50\% of the total Isoetes lacustris production), but would still remain a low production value. In contrast, $I$. delilei leaf productivity $\left(677 \mathrm{~g} \mathrm{DW} \mathrm{m}^{-2} \mathrm{y}^{-1}\right)$ is much higher and similar to the range described for other submerged species of 300-1500 g DW m ${ }^{-2} \mathrm{y}^{-1}$ (Madsen et al., 2002 and references therein) as shown in figure 4 . The higher I. delilei production could be related to higher nutrient availability in the studied pool in comparison to the oligotrophic soft-water lakes where other isoetids often dominate and to a higher degree of adaptation to emersion. Emersion not only seems to enhance productivity for this amphibious Isoetes but also for helophyte species that generally show high annual production (Yu et al., 2010; Silva et al., 2013; Tamire \& Mengistou, 2014).

The important production increase of both studied Isoetes species when emerged may have future consequences under a climate change scenario with rainfall regime shifts and temperature increase. The rainfall reduction expected in the Mediterranean region could negatively affect $I$. delilei thriving in temporary pools, which already have low rainfall, if the initial wet phase does not occur or is too short. In contrast, a rainfall reduction in the Pyrenees, which is currently high, could enhance the creation of more temporary environments and potentially increase I. echinospora production. Isoetes spore production only occurs above a minimum temperature of about $10^{\circ} \mathrm{C}$ (Vöge, 2006) and percent of germination increases with temperature (Ctvrtlikova et al., 2012; Ctvrtlikova et al., 2014). However, high temperatures $\left(17^{\circ} \mathrm{C}\right)$ desynchronize the phenology of germination (Ctvrtlikova et al., 2012). Hence, depending on the ecosystem and the temperature increase, plant density and primary production will be whether enhanced or reduced.

\section{ACKNOWLEDGEMENTS}

This study was funded by Intramural CSIC (Consejo Superior de Investigaciones Científicas) project, ref. 0065. EC was supported by a I3P grant fellowship from the Spanish Research Council (CSIC). EG and EC are members of the Environmental Changes Ecology Group (GECA), an Excelence Research Group (SGR-DGR) of Generalitat de Catalunya (Ref. 2014 SGR 1249. 2014-2017). We are grateful to Matthew Anderson for English language editing. We acknowledge two anonymous referees for useful comments on a previous version of the manuscript.

\section{REFERENCES}

BAGELLA, S. \& M. C. CARIA. 2012. Diversity and ecological characteristics of vascular flora in Mediterranean temporary pools. Comptes Rendus Biologies, 335(1): 69-76.

BOIVIN, B. 1961. Isoetes echinospora Durieu in North America. American Fern Journal, 51(2): 83-85.

BOSTON, H. L. \& M. S. ADAMS. 1987. Productivity, growth and photosynthesis of two small isoetid plants, Littorella uniflora and Isoetes macrospora. Journal of Ecology, 75(2): 333-350.

BOSTON, H. L., M. S. ADAMS \& J. D. MADSEN. 1989. Photosynthetic strategies and productivity in aquatic systems. Aquatic Botany, 34(1-3): 27-57.

CASANOVA, M. T. \& M. A. BROCK. 2000. How do depth, duration and frequency of flooding influence the establishment of wetland plant communities? Plant Ecology, 147(2): 237-250.

CATALAN, J., E. BALLESTEROS, L. CAMARERO \& E. GACIA. 1990. Aspectos generales de la limnología invernal de dos lagos pirenaicos morfológicamente muy distintos (Estany Redó y Estany Baciver). Scientia Gerundensis, 16(2): 55-68.

CATALAN, J., L. CAMARERO, M. FELIP, S. PLARABES, M. VENTURA, T. BUCHACA, F. BARTUMEUS, G. DE MENDOZA, A. MIRÓ, E. O. CASAMAYOR, J. M. MEDINA SÁNCHEZ, M. BACARDIT, M. ALTUNA, M. BARTRONS \& D. 
DÍAZ DE QUIJANO. 2006. High mountain lakes: extreme habitats and witnesses of environmental changes. Limnetica, 25(1-2): 551-584.

CHAPPUIS, E., E. GACIA \& E. BALLESTEROS. 2014. Environmental factors explaining the distribution and diversity of vascular aquatic macrophytes in a highly heterogeneous Mediterranean region. Aquatic Botany, 113: 72-82.

CHAPPUIS, E., A. LUMBRERAS, E. BALLESTEROS \& E. GACIA. 2015. Deleterious interaction of light impairment and organic matter enrichment on Isoetes lacustris (Lycopodiophyta, Isoetales). Hydrobiologia, 760(1): 145-158.

CTVRTLIKOVA, M., P. ZNACHOR, J. NEDOMA \& J. VRBA. 2012. Effects of temperature on the phenology of germination of Isoetes echinospora. Preslia, 84(1): 141-153.

CTVRTLIKOVA, M., P. ZNACHOR \& J. VRBA. 2014. The effect of temperature on the phenology of germination of Isoetes lacustris. Preslia, 86(3): 279-292.

DEIL, U. 2005. A review on habitats, plant traits and vegetation of ephemeral wetlands - a global perspective. Phytocoenologia, 35(2-3): 533-705.

DING, W. X., Z. C. CAI, H. TSURUTA \& X. P. LI. 2003. Key factors affecting spatial variation of methane emissions from freshwater marshes. Chemosphere, 51(3): 167-173.

FLOR-ARNAU, N., M. REAL, G. GONZALEZ, J. C. SANCHEZ, J. L. MORENO, C. SOLA \& A. MUNNE. 2015. The Fluvial Macrophyte Index (IMF), a new tool to assess the ecological status of Mediterranean rivers. Limnetica, 34(1): 95-114.

GACIA, E. \& E. BALLESTEROS. 1991. Two methods to estimate leaf production in Isoetes lacustris L.: a critical assessment. Verhandlungen des Internationalen Verein Limnologie, 24: 2714-2716.

GACIA, E. \& E. BALLESTEROS. 1993. Diel acid fluctuations in Pyrenean Isoetes species -The effects of seasonality and emersion. Archiv für $\mathrm{Hy}$ drobiologie, 128(2): 187-196.

GACIA, E. \& E. BALLESTEROS. 1994. Production of Isoetes lacustris in a Pyrenean lake: seasonality and ecological factors involved in the growing period. Aquatic Botany, 48(1): 77-89.

GACIA, E., E. BALLESTEROS, L. CAMARERO, O. DELGADO, A. PALAU, J. L. RIERA \& J. CATALAN. 1994. Macrophytes from lakes in the eastern Pyrenees: community composition and ordina- tion in relation to environmental factors. Freshwater Biology, 32(1): 73-81.

GREUTER, W. \& A. TROIA. 2015. Disentangling Isoetes setacea and removing threats to Isoetes echinospora. Taxon, 64(4): 811-815.

KRAUSE, W. \& J. J. KING. 1994. The ecological status of Lough Corrib, Ireland, as indicated by physiographic factors, water chemistry and macrophytic flora. Vegetatio, 110(2): 149-161.

MABERLY, S. C. \& D. H. N. SPENCE. 1989. Photosynthesis and photorespiration in fresh-water organisms. Amphibious plants. Aquatic Botany, 34(1-3): 267-286.

MADSEN, T. V., B. OLESEN \& J. BAGGER. 2002. Carbon acquisition and carbon dynamics by aquatic isoetids. Aquatic Botany, 73(4): 351-371.

MILLER, R. L. \& R. FUJII. 2010. Plant community, primary productivity, and environmental conditions following wetland re-establishment in the Sacramento-San Joaquin Delta, California. Wetlands Ecology and Management, 18(1): 1-16.

MOLINA, J. A. 2005. The vegetation of temporary ponds with Isoetes in the Iberian Peninsula. Phytocoenologia, 35(2-3): 219-230.

MURPHY, K. J. 2002. Plant communities and plant diversity in softwater lakes of northern Europe. Aquatic Botany, 73(4): 287-324.

NIELSEN, S. L. \& K. SAND-JENSEN. 1997. Growth rates and morphological adaptations of aquatic and terrestrial forms of amphibious Littorella uniflora (L) Aschers. Plant Ecology, 129(2): 135-140.

NÕGES, T., H. LUUP \& T. FELDMANN. 2010. Primary production of aquatic macrophytes and their epiphytes in two shallow lakes (Peipsi and Võrtsjärv) in Estonia. Aquatic Ecology, 44(1): 83-92.

OBRADOR, B. \& J. L. PRETUS. 2010. Spatiotemporal dynamics of submerged macrophytes in a Mediterranean coastal lagoon. Estuarine Coastal and Shelf Science, 87(1): 145-155.

PENNING, W., M. MJELDE, B. DUDLEY, S. HELLSTEN, J. HANGANU, A. KOLADA, M. VAN DEN BERG, S. POIKANE, G. PHILLIPS, N. WILLBY \& F. ECKE. 2008. Classifying aquatic macrophytes as indicators of eutrophication in European lakes. Aquatic Ecology, 42(2): 237-251.

PFEIFFER, N. E. 1922. Monograph of the Isoetaceae. Annals of the Missouri Botanical Garden, 9(2): 79-233. 
POKORNÝ, J. \& J. KVĚT. 2003. Aquatic plants and lake ecosystems. in: The lakes handbook: limnology and limnetic ecology. P. O'Sullivan \& C. S. Reynolds (eds.). Blackwell Science Ltd, Malden, MA, USA.

RHAZI, L. 2010. Isoetes setacea. The IUCN Red List of Threatened Species. Version 2015.2. URL: http://www.iucnredlist.org/details/163983/0

RHAZI, M., P. GRILLAS, A. CHARPENTIER \& F. MEDAIL. 2004. Experimental management of Mediterranean temporary pools for conservation of the rare quillwort Isoetes setacea. Biological Conservation, 118(5): 675-684.

ROBE, W. E. \& H. GRIFFITHS. 1998. Adaptations for an amphibious life: changes in leaf morphology, growth rate, carbon and nitrogen investment, and reproduction during adjustment to emersion by the freshwater macrophyte Littorella uniflora. New Phytologist, 140(1): 9-23.

SAND-JENSEN, K. \& H. FROST-CHRISTENSEN. 1999. Plant growth and photosynthesis in the transition zone between land and stream. Aquatic Botany, 63(1): 23-35.

SAUNDERS, M. J., F. KANSIIME \& M. B. JONES. 2014. Reviewing the carbon cycle dynamics and carbon sequestration potential of Cyperus papyrus L. wetlands in tropical Africa. Wetlands Ecology and Management, 22(2): 143-155.

SEDDON, B. 1965. Occurrence of Isoetes echinospora in eutrophic lakes in Wales. Ecology, 46(5): 747-748.

SILVA, T. S. F., M. P. F. COSTA \& J. M. MELACK. 2009. Annual net primary production of macrophytes in the eastern Amazon floodplain. Wetlands, 29(2): 747-758.

SILVA, T. S. F., J. M. MELACK \& E. M. L. M. NO-
VO. 2013. Responses of aquatic macrophyte cover and productivity to flooding variability on the Amazon floodplain. Global Change Biology, 19(11): 3379-3389.

SMOLDERS, A. J. P., E. C. H. E. T. LUCASSEN \& J. G. M. ROELOFS. 2002. The isoetid environment: biogeochemistry and threats. Aquatic Botany, 73: 325-350.

TAMIRE, G. \& S. MENGISTOU. 2014. Biomass and net aboveground primary productivity of macrophytes in relation to physico-chemical factors in the littoral zone of Lake Ziway, Ethiopia. Tropical Ecology, 55(3): 313-326.

VERSPAGEN, J. M. H., D. B. VAN DE WAAL, J. F. FINKE, P. M. VISSER \& J. HUISMAN. 2014. Contrasting effects of rising $\mathrm{CO}_{2}$ on primary production and ecological stoichiometry at different nutrient levels. Ecology Letters, 17(8): 951-960.

VILA-COSTA, M., C. PULIDO, E. CHAPPUIS, A. CALVIÑO, E. O. CASAMAYOR \& E. GACIA. 2016. Macrophyte landscape modulates lake ecosystem-level nitrogen losses through tightly coupled plant-microbe interactions. Limnology and Oceanography, 61(1): 78-88.

VÖGE, M. 2006. The reproductive phenology of Isoetes lacustris L.: Results of field studies in Scandinavian lakes. Limnologica, 36(4): 228-233.

WETZEL, R. G. 1981. Limnología. Omega. Barcelona.

WHITTAKER, R. H. \& G. E. LIKENS. 1973. Primary production: the biosphere and man. Human Ecology, 1(4): 357-369.

YU, J. B., J. S. LIU, F. X. MEIXNER, J. D. WANG, Y. J. GAO, Y. WANG, X. N. QI \& X. B. CHEN. 2010. Estimating net primary productivity and nutrient stock in plant in freshwater marsh, Northeastern China. Clean-Soil Air Water, 38(11): 1080-1086. 